\title{
A formative evaluation of a Web-based tutorial
}

\author{
SM Meyer, MEd (CAE), Department of Nursing Science, University of Pretoria
}

\section{Abstract}

Lecturers of the Department of Nursing Science of the University of Pretoria (UP) were requested to participate in an informal evaluation of a software program. The software evaluated were developed as a tutorial by the author of this article. The content of the tutorial concerns the current issues of the new education and training dispensation in South Africa, and specifically how to compile unit standards to meet the requirements of the South African Qualifications Authority (SAQA) and the National Qualifications Framework (NQF).

The purpose of the evaluation was to assess the quality of the software. Participants were provided with a questionnaire, as well as criteria for the evaluation of software as presented in literature and information on the Web. The feedback has been useful and suggestions made by the participants have been used to improve and add to the product.

\section{Abstrak}

Lektore van die Departement Verpleegkunde van die Universiteit van Pretoria (UP) was versoek om aan " $n$ informele evaluering van " $n$ sagteware program deel te neem. Die sagteware wat evalueer moes word is ontwikkel as ' $n$ tutoriaal deur die outeur van hierdie artikel. Die inhoud van die tutoriaal fokus op die huidige tendense van die onderwys en opleiding situasie in Suid Afrika. Dit fokus spesifiek op hoe om eenheid standaarde te stel ten einde aan die vereistes van die Suid Afrikaanse Kwalifikasie Outoriteit (SAKO) en die Nasionale Kwalifikasie Raamwerk (NKR) te voldoen. Die doel van die evaluering was om die kwaliteit van die sagteware te meet. Deelnemers is voorsien van " $n$ vraelys, sowel as kriteria vir die evaluering van die sagteware soos verkry in die literatuur en inligting vanaf die Web. Terugvoer van die deelnemers was baie bruikbaar en voorstelle wat gemaak is, is gebruik om die produk te verbeter en byvoegings te maak.

\section{Introduction}

Since the introduction of the Internet and the World-WideWeb, information of all kinds became available to every person who is computer literate. To obtain information $/ \mathrm{knowledge}$ is not the biggest issue, but rather what is being done with that information and how it is applied. The emphasis should now shift from obtaining information, to using the information/ knowledge at one's disposal to improve one's skills.

All information available on the Web is not necessarily of high quality and will not enhance learning. The same applies to software developed for educational purposes. Before any software can be incorporated into a program as part of lecturer or student support, it must first be evaluated.

The ideal evaluator/assessor would be somebody who is computer literate and who is a specialist in his/her subject. In order to ensure an objective assessment, more than one person should do the evaluation.

\section{Problem Statement}

The author has developed software, which is published on the Web. The subject of the software falls within the context of the new requirements of the South African government on education and training, namely The Compilation of Unit Standards as required by the National Qualifications Framework (NQF). All lecturers of the Department of Nursing Science at the University of Pretoria were invited to participate. The purpose of the software is for lecturers who have to develop curricula according to the SAQA requirements, to gain insight into the development of unit standards by first doing the tutorial which provides opportunity for exercises.

\section{Background of the Problem}

Computer literacy has become a key phrase in defining the aim of many educational institutions. It is, however, important to note that people must be literate, implying being able to read and write, before they will be able to become computer literate. Computers are limited in their teaching abilities, and man will always be the better teacher (Barlow, 1999). This statement can lead to many a debate, but the important issue here is that educational software will only be as good as the person who created it.

Educational software/technology has a definite place in education as it allows students to use it as often as they deem necessary, especially if a lecturer is not available. Computer literacy has become part of the general frame of reference of many educators. Information associated with computers and the Internet is the new focus point in obtaining information and acquiring new skills.

Computer software can be employed as support tools to obtain information regarding subject matter pertaining to a myriad of educational situations. It also serves as an excellent tool for in-service training or continued learning for adults/lecturers as they can study the content of a specific software program in their own time, as well as repeat the lesson/tutorial as often as they would like to.

Tutorial-type computer software presents learners with information or skills, and guide them through the application of the newly acquired information, knowledge and skills (Alessi \& Trollip, 1991:17). Instructional tools/tutorials demand an alter- 
Figure 1: The introductory page of the web site on the Principles of the NQF

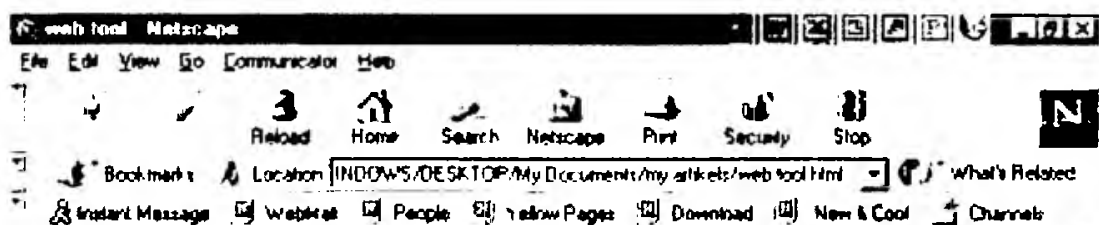

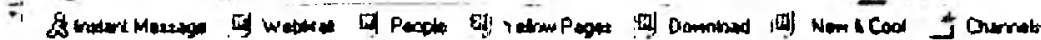

\section{Principles of the NQF}

4, 0 to Powerfoint slicto shour on the compilation of unit st andat ds for intormation on the principles underlying the Ma

HACK

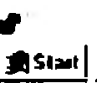

londex

Docamor Done

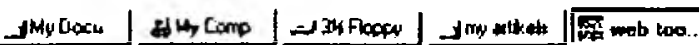

110.111

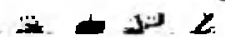

ogy " assisted education. The role that technology should play in nursing education should be as Gentry (1987:3) describes it: "Technology should be the servant and not the master of instruction. It should not be adopted merely because it exists, or because an institution fears that it will be left behind the parade of progress without it".

\section{Criteria for the evaluation of software}

According to Trochim (1999:1), evaluation is probably mostly defined as "...the systematic assessment of the worth or merit of an object". However, evaluation does not always result in the assessment of worth. Trochim (1999:1) provides another, probably more accurate definition: "Evaluation is the systematic acquisition and assessment of information to provide useful feedback about some object." The "object" in this instance, is a web-based tutorial.

Evaluation/assessment of educational software is not an easy task. There are two reasons for

native way of thinking regarding the use of computers in education (Blignaut \& Knoetze, 1999). Students must, however, not be forced to rely on computer skills only to meet the outcomes of programs. Educational software alone cannot influence the cognitive development of a student. Human intervention in the form of the educator is therefore imperative.

What needs to be established is the quality of software used for continued learning or in-service training. All software programs do not contain useful information and are not necessarily user-friendly. Therefore, many instructional designers have written on the subject of evaluating software regarding the applicability of content, interface design, and usability.

If one considers the computer and computer software as part of educational strategies, it could be described as "technol- evaluating/assessing software: 1) to improve the instructional possibilities and 2) to improve the quality of the software per se. The evaluation can be done in both an informal and formal manner (Hannafin \& Peck, 1988: 279). Evaluation provides feedback, useful or otherwise. There are mainly two forms of evaluation namely formative and summative evaluation. Formative evaluation assists the development of an object, as it can be developed and improved as people evaluate and give feedback on the quality, applicability and usability of the object. Summative evaluation is the final evaluation regarding the impact of the object on outcomes (Trochim, 1999).

It is of the essence to establish whether or not specific software complies with set criteria, and also whether it will assist the user/learner/lecturer towards the achievement of pre-de-

Figure 2 : One slide of the MS PowerPoint slide show

Field and sub-field within which

the unit standard apply

The possible fields and sub-fields to which the unit standards apply should be indicated

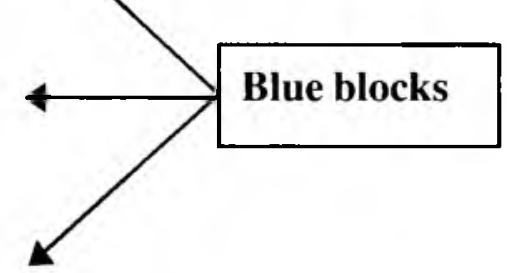

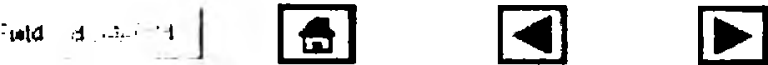


termined goals, aims, objectives or outcomes. Various methods can be employed to establish whether the selected software complies with the set requirements, and whether or not it can be used effectively for educational purposes. According to Hannafin \& Peck (1988:279), the evaluation of computerassisted instruction is "an ongoing process that occurs continuously, drawing on a variety of information sources and techniques."

\section{The software evaluated}

The author requested lecturers who are computer literate to volunteer for this project and five lecturers decided to participate. The participants were asked to evaluate the Web based tutorial. The tutorial consisted of the following parts:

The Compilation of Unit Standards as required by the National Qualifications Framework (NQF) was created in Netscape Composer. It also contains a resource list at the end of the site, with Universal Relative Links (URL's), providing the user with the opportunity of visiting the sites with information of SAQA,

- $\quad$ A Microsoft (MS) PowerPoint slide show, Compiling Unit Standards (A support tool), has been linked to certain sections of the tutorial.

A glossary containing relative terminology was added to the html document. The purpose of this is to assist the user in understanding the paradigm shift regarding education and mastering the new educational "language". The purpose of the slide show was to provide the user with additional information on the compilation of unit standards. The tutorial was available on the server of the University of Pretoria (UP), and therefore the participants, who have computers in their offices linked to the Intranet of the UP. They were assisted by the author in accessing the Intranet, and to work through the tutorial. No graphics were used in the creation of the web site. The "home" and "back" buttons were, however, animated. The background of the buttons reflected a light green, with the letters of the word "back" and "home" a darker green, and appearing one by one, again and again. The background colour of the site was dark orange, and the font used, Lucida sans Unicode 10 bold in royal blue. A one-pixel frame, with a cream background framed the headings of the different sections. The font that was used for the heading was in Parisian BT 24 bold. Links were made in bright yellow. See Figure 1 to assist description.

The MS PowerPoint slide show, Compiling Unit Standards (A support tool) linked to the site, was created on a Microsoft template, and the original green background changed to blue. The background contains a few stationary "ribbons" in shades

\section{Table 1: Evaluation criteria as adapted from that of Joseph (1999)}

\begin{tabular}{|l|}
\hline 1. General appearance \\
\hline 2. Ease of navigation \\
\hline 3. Graphics \\
\hline 4. Content/information \\
\hline 5. Further information \\
\hline
\end{tabular}

of blue, with a "block" floating from left to right over the top third of the screen for approximately three seconds each time the user clicked on the "next" button. The font used for the slide show is Gill sans 32 in pale blue, with some of the slides with pop-up boxes created in Visual Basic, and containing definitions and explanations of the concepts of specific slides. The background of the pop-up boxes was medium blue, with the text in a pale blue font of Gill Sans 12 .

See Figure 2 to assist description.

\section{Purpose of the study}

The purpose of the study was to assess the quality of the software that was developed, and to improve the product if and where necessary.

\section{Methods and procedures}

Participants were provided with evaluation criteria. The evaluation form of Joseph (1999) was adapted and provided to assist them in the evaluation of the tutorial, as they had no prior knowledge regarding the criteria for the evaluation of software. Please see table one for these evaluation criteria. The software has been developed and finished in totality before the participants did the evaluation thereof.

All five participants are computer literate, but on different levels. Please see table two in this regard. They did not find it too difficult to work through the tutorial. The participants were allowed to ask each other for assistance when they did not understand how to continue with the tutorial. They spontaneously asked the author for assistance when it was needed. After the participants have worked through the tutorial a focus group discussion took place to get feedback. Field notes were taken and added to the data obtained from the evaluation forms. During the focus group participants were allowed to talk to each other and therefore the clarity of the findings were enhanced. The roles performed by the five participants were that of evaluator, advisor and critic.

The feedback on this software served a formative purpose, as the author of the web-based tutorial used the information to improve the product and it will be used for the development of future nursing educational software programs.

\section{Table 2: Computer literacy level of lecturers}

\begin{tabular}{|l|l|l|l|l|l|}
\hline Lecturer & No. 1 & No. 2 & No. 3 & No. 4 & No. 5 \\
\hline $\begin{array}{l}\text { Average hours } \\
\text { working on the } \\
\text { computer per day }\end{array}$ & 8 & 6 & 2 & 2 & 2 \\
\hline Used MS Word before & Yes & Yes & Yes & Yes & Yes \\
\hline $\begin{array}{l}\text { Used MS PowerPoint } \\
\text { before }\end{array}$ & No & No & No & No & No \\
\hline $\begin{array}{l}\text { Use software sources } \\
\text { for my students }\end{array}$ & Yes & No & No & No & No \\
\hline $\begin{array}{l}\text { Browsed the Internet } \\
\text { before }\end{array}$ & Yes & Yes & No & No & No \\
\hline
\end{tabular}




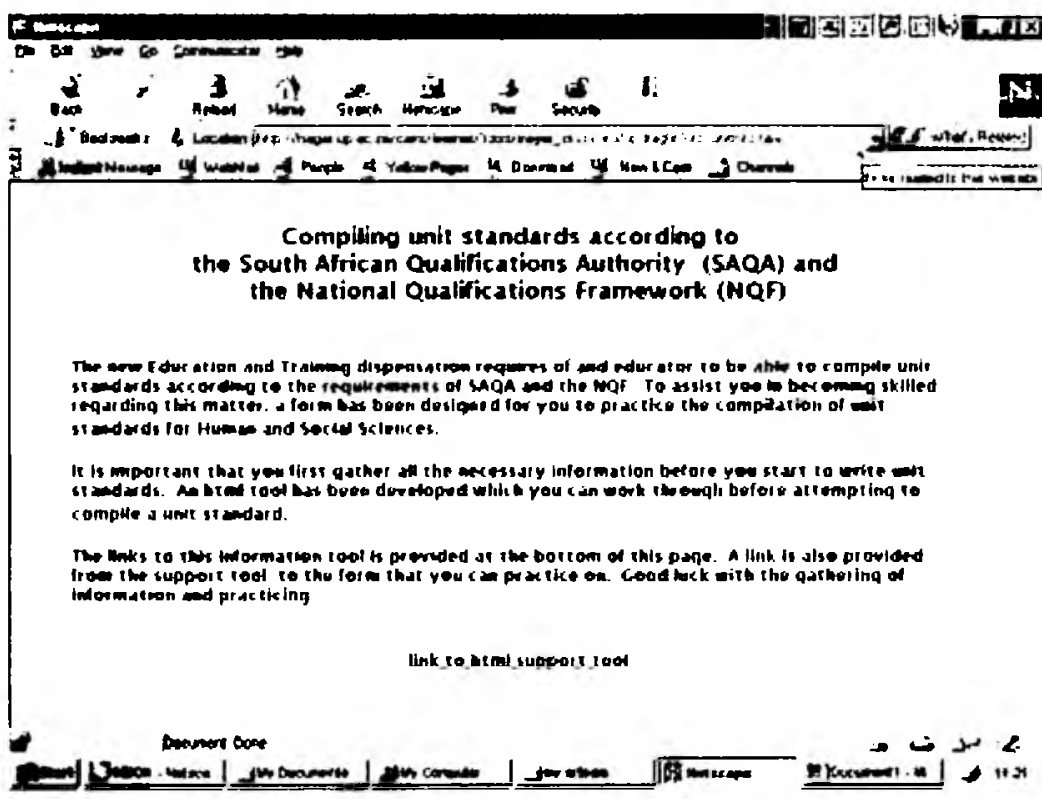

\section{Information/evaluation criteria provided to participants}

The definition by Hannafin and Peck (1988:303) was provided: "Instructional adequacy is the extent to which the lesson provides the necessary kinds of support and features to accomplish the objective at hand". The following information on lesson procedure, clarity, efficiency and design of a lesson for the computer from Hannafin and Peck was also supplied:

- Lesson activities must be easy to follow

- Instructions must be clear and unambiguous

- Instructions must be consistently presented throughout

- Basic design of the lesson must be sensible and userfriendly

- The information presented (test, graphics, animation. and sound) must be readily interpreted

\section{Figure 4: Sitemap for tutorial}

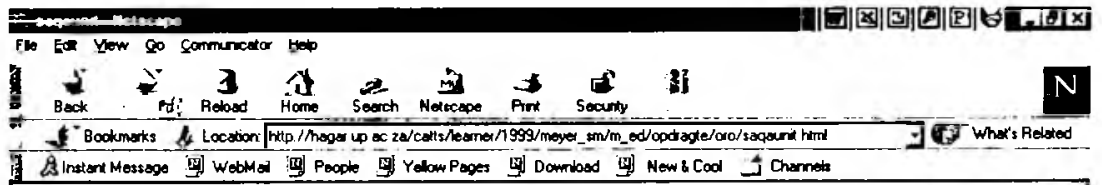

\section{The compilation of Unit standards as required by the \\ National Qualifications Framework (NQF)}

- The aim of this web site is to serve as a support tool for a lecturer of the Human and Social

Sclences Learning area.

The support tool aims to assist the lecturer in the compilation of unit standards according to the requirements as set out by the South Afric an Quallfications Authority who compiled the

NQF.

- The educator will be able to link to different support tools of which the links are provided at the end of this site.
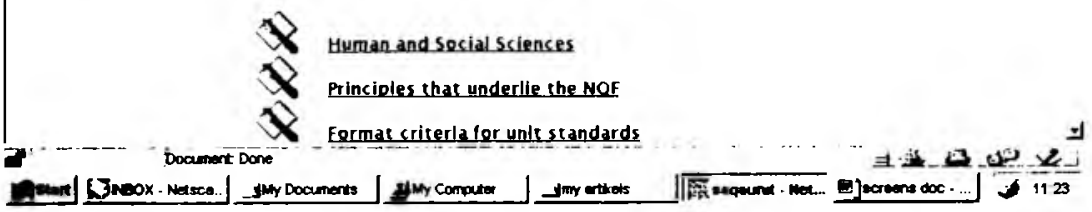

Lessons should avoid unnecessary and distracting information

The placement/design/colour of instructions should be consequent throughout the lesson The following general criteria for the evaluation of software found on the web-site of the Department of Library Studies and Educational Technology of the East Carolina University, were provided:

"The software program should:

- Follow educationally sound principles of instruction

- Use the computer's capabilities advantageously

- $\quad$ Provide interaction between user, computer and program

- $\quad$ Provide sufficient information for the user to solve problems, reach conclusions, grasp a concept, and learn a skill or process".

Additional information on the following to take into consideration when evaluating the software, was provided from http://hagar.up.ac.za/catts/ole/eel/concept-map/cosmet2.html:

Specific criteria on screen design regarding the evaluation of user-friendliness,

the evaluation of visual display, such as the use of:

$>$ colour

$>\quad$ graphics

$>$ menus

$>$ icons

\section{Data analysis}

Findings

The Web-site

Negative aspects:

The default setting of the font of the computers of the participants influenced the opinion regarding legibility, the reason for this being that one participant's opinion regarding the font size was that "the letters were too small and reading difficult". It seemed that the font was set as Times New Roman 10 regular and that the font used for the site was Gill sans 12 bold. The participant was, however, of the opinion that it might be the background and font colours causing the illegibility.

- One participant was actually expecting a lit tle more "excitement". She was, however, the participant with the most computer ex perience. She was obviously used to browsing the Internet, although the author doubts whether the sites visited by this participant had all been educational in nature.

- The animated home and back buttons bothered only one participant. Her comment was that the flickering was "distracting".

- The grammar was bothering two participants as one found a spelling mistake, and the other found the sentences to be abrupt.

- Most of the participants requested a contact link to the author on the site but the author deemed this unnecessary. The soft- 


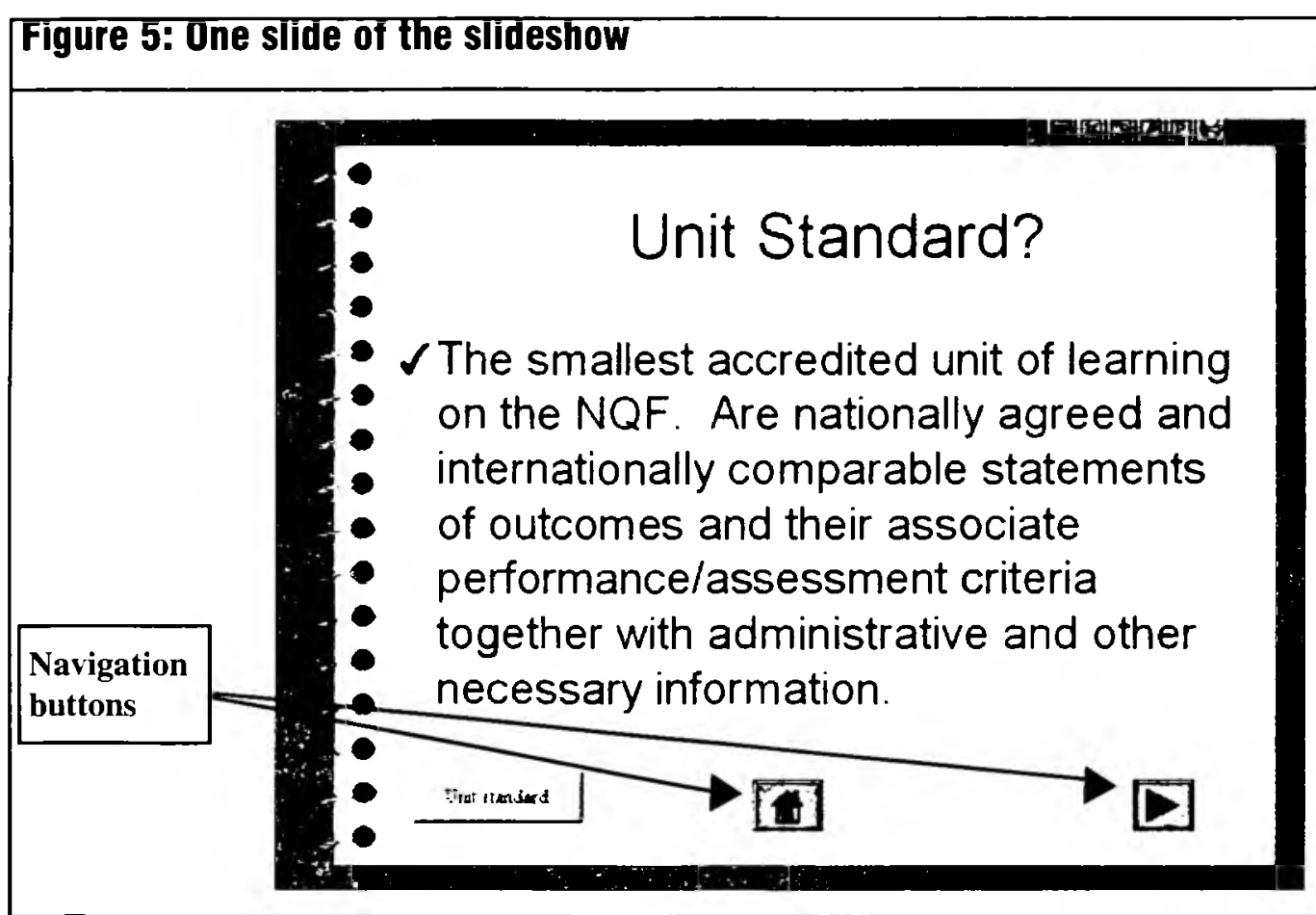

ware program. The Compilation of Unit Standards as required by the National Qualifications Framework (NQF), was linked from the author's personal web site. The back button of the software takes one back to the author's personal web site.

Positive aspects:

The majority of the participants found the web site and the slide show to be quite useful. The following comments were made:

- Colour combination discriminates well between main and sub ideas

- Generally user-friendly

- Like the resource links

- Information correct, logical and factual

- Favour the colour combination

- $\quad$ Background not overbearing

- $\quad$ Font type legible

Figure 6: Slide of the slideshow with textbox open

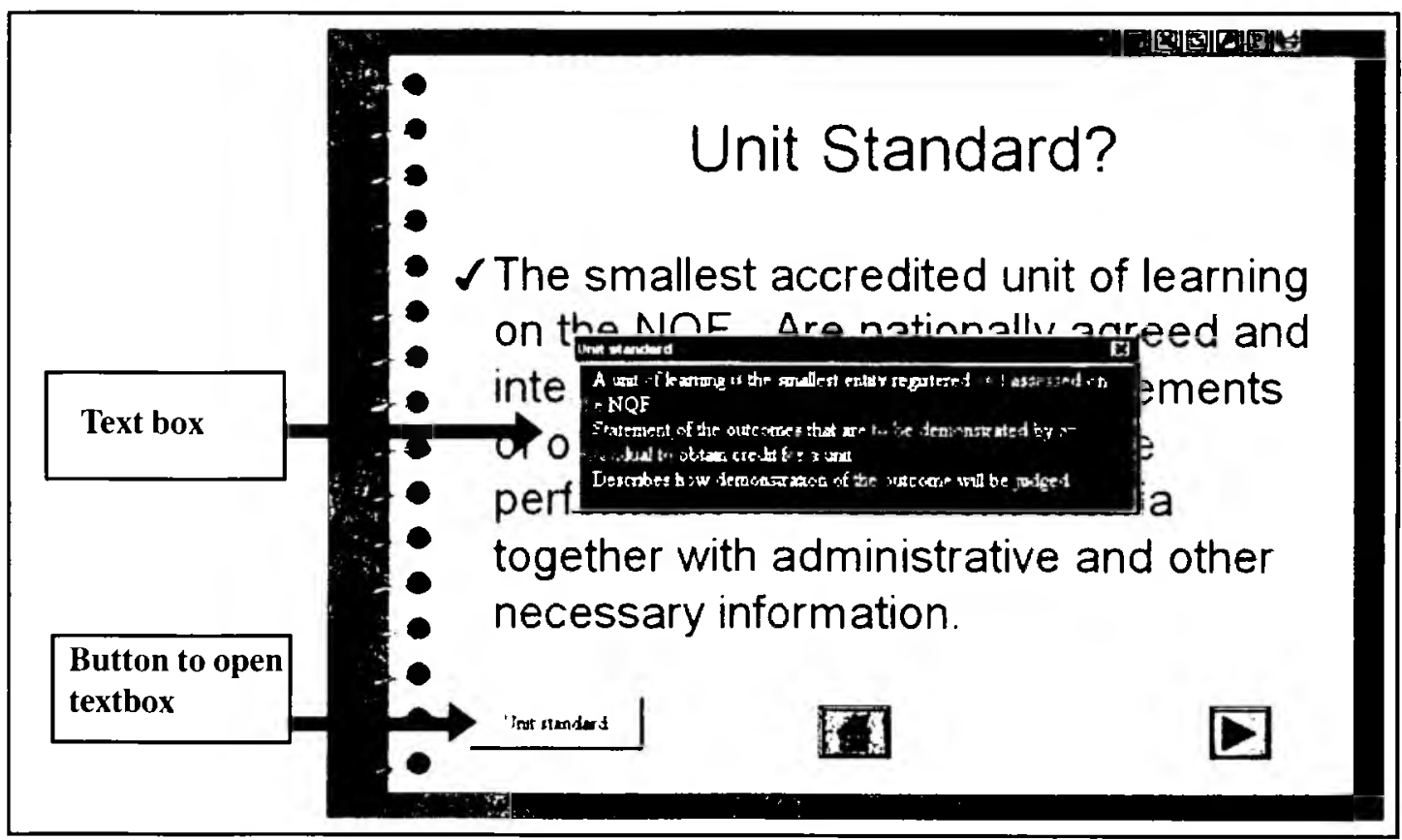

The slide-show

Negative aspects:

Aspects identified were:

- The blue block (see figure 2) moving slowly over the top of the screen was irritating and creating frustration as one could not move to the next slide before it stopped moving.

- $\quad$ Each link in the web site was linked to the home/ first page of the slideshow. The participants would have preferred it linked to the specific slide applicable. However, the author was of the opinion that it was unnecessary, as the slide show contained a menu of the topics.

Positive aspects:

The majority of the comments on the slide show were positive:

- Good colour combination

- Information relevant, applicable and correct

- $\quad$ Font type and colour makes reading easy

\section{Changes}

The following changes were made to the html document:

- An informative, more personal introduction that addresses the user was written called Compiling unit standards according to the South African Qualifications Authority (SAQA) and the national Qualifica tions Framework (NQF). The background is white with the characters in a font of bold Gill Sans of 12 points. A link to the html document called The compilation of Unit standards as required by the National Qualifications Framework (NQF) is provided at the bottom of the screen (see figure 3 ).

- The sitemap of the html document was changed completely. It was given a white background. The heading was put in a frame of one pixel with a blue background and the title in white in a font of Gill Sans bold 20 points. An icon was used for aesthetic pur poses before every link to the different parts of the document (see figure 4). For the text Gill Sans in bold point 12 in blue was used.

- A completely different template of MS 
Figure 7: MS Access tool to practice writing unit standards

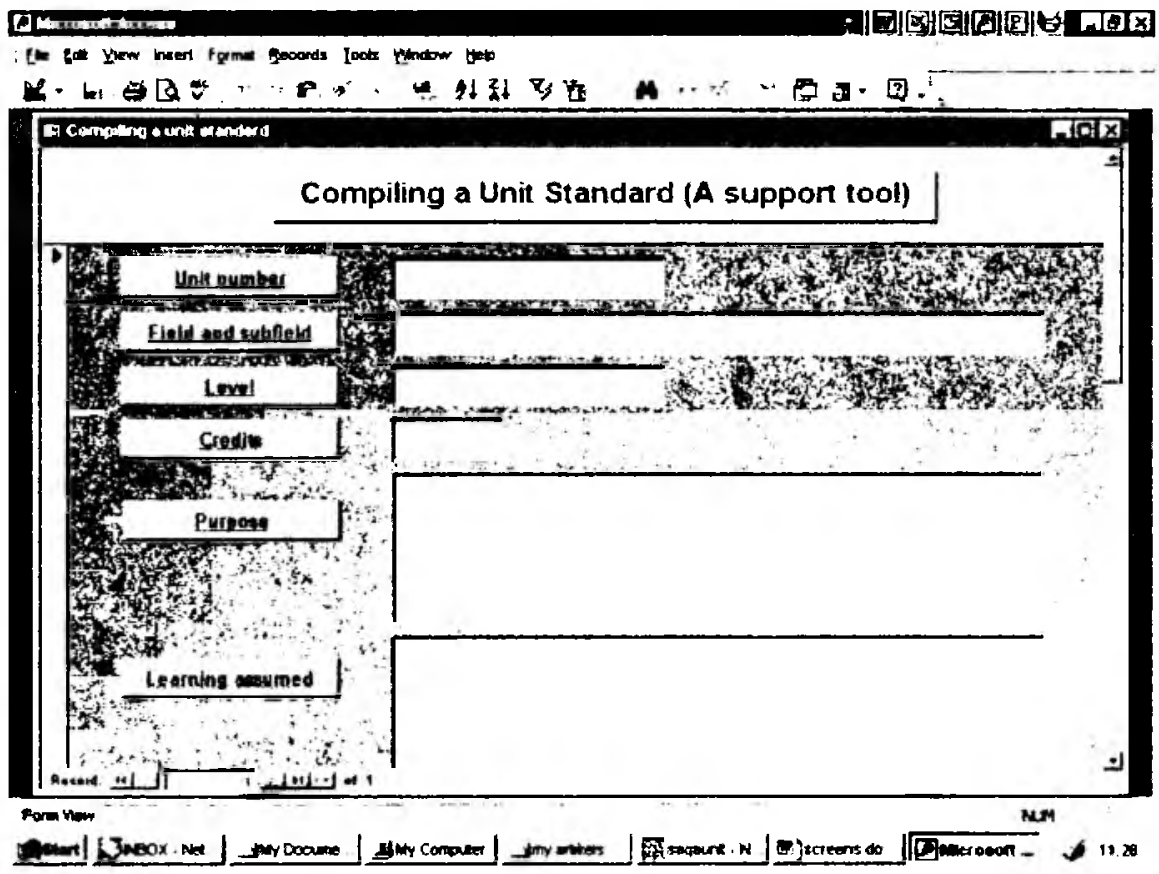

ards (see figure 8). After every exercise the user can clear the form and start over again.

- A Microsoft Word document, Guidelines for using the Access software to compile a unit standard, to guide the user on how to use the support tool created in MS Access (see figure 10).

To enable the user to use the MS Access tool it was necessary to provide the user with guidelines. These are provided in the MS Word document. A link on the html file provides information and a link to the document (see figure 9).

\section{Conclusion}

The evaluation that was done has been a positive experience for both the author of the software, as well as the participants. The web site

PowerPoint was used for the slide show. The template looks like a notebook. The colours are different shades of brown.

The font used is Ariel in brown in a large point size. The slides contain navigational links (see figure 5).

- To assist the user in gaining additional information regarding unit standards, buttons to open text boxes containing that information was designed on the slides (see figure 6).

The following additions were made to the html document:

- A Microsoft Access database, Compiling a Unit Standard (A support tool), that provides in formation as well as an opportunity to practice writing unit standards (see figure 7). This tool was also provided with buttons that can open text boxes containing information on aspects of unit stand-

\section{Figure 8: MS Access form on which a button has been clicked to open the text box with information}

called The Compilation of Unit Standards as required by the National Qualifications Framework ( $N Q F$ ) has been improved. The initial tutorial lacked interactivity and opportunity to practice. The evaluation of the tutorial resulted in a valuable learning experience for the author. The author is of the opinion that there is definitely a place for tutorials of this nature in a personnel development or further education programme. This tutorial can be viewed at http://hagar.up.ac.za/ catts/learner/1999/meyer_sm/m_ed/opdragte/oro/unitinfo.htm

\section{References}

ALESSI, SM \& TROLLIP, SR 1991: Computer-Based Instruction: Methods and Development, $2^{\text {nd }}$ Edition. Prentice Hall: New Jersey.

- BARLOW, Z 1999: Learning in the Real world: Computers' Role in Education. http://www_realword_org.html

BENNETT, F 1996: Computers as Tutors: Solving the Crisis in Education. http://www.cris.com/ $\sim$ Faben $1 /$

BLIGNAUT, AS \& KNOETZE, JG 1999: The Use of Computer-based Instructional Tools in Teaching and Learning.

http://www.up.ac.za/academic/education/didactics/ modules/mio880/resources.htm

GENTRY, CG 1987: Educational Technology: A Question of Meaning. Educational Media and Technology Year book 1987. CO: Libraries Unlimited.

HALL, B 1998: Web-based Training Cookbook. 1.7 John Wiley \& Sons: New York. 
Figure 9: The information and link on the $\mathrm{html}$ tool to the

\section{MS Word document}

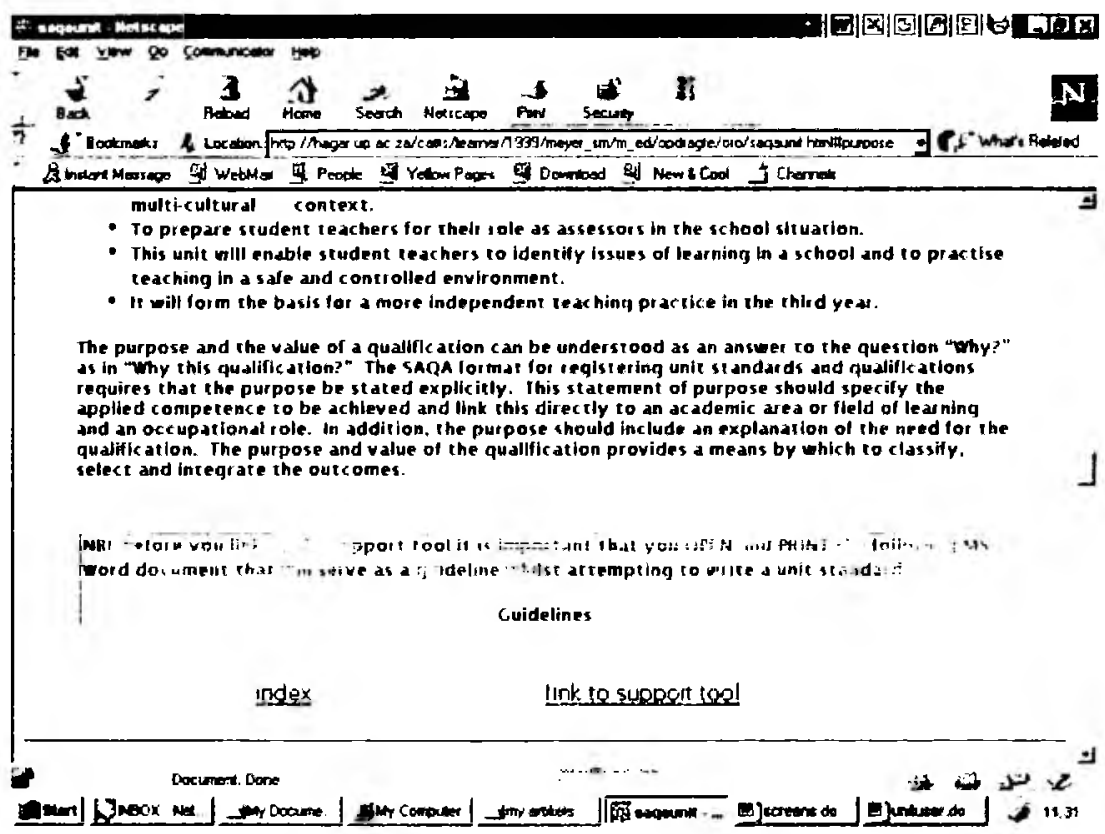

\section{Figure 10: A Microsoft Word document to guide the user on how to use the support tool created in MS Access}

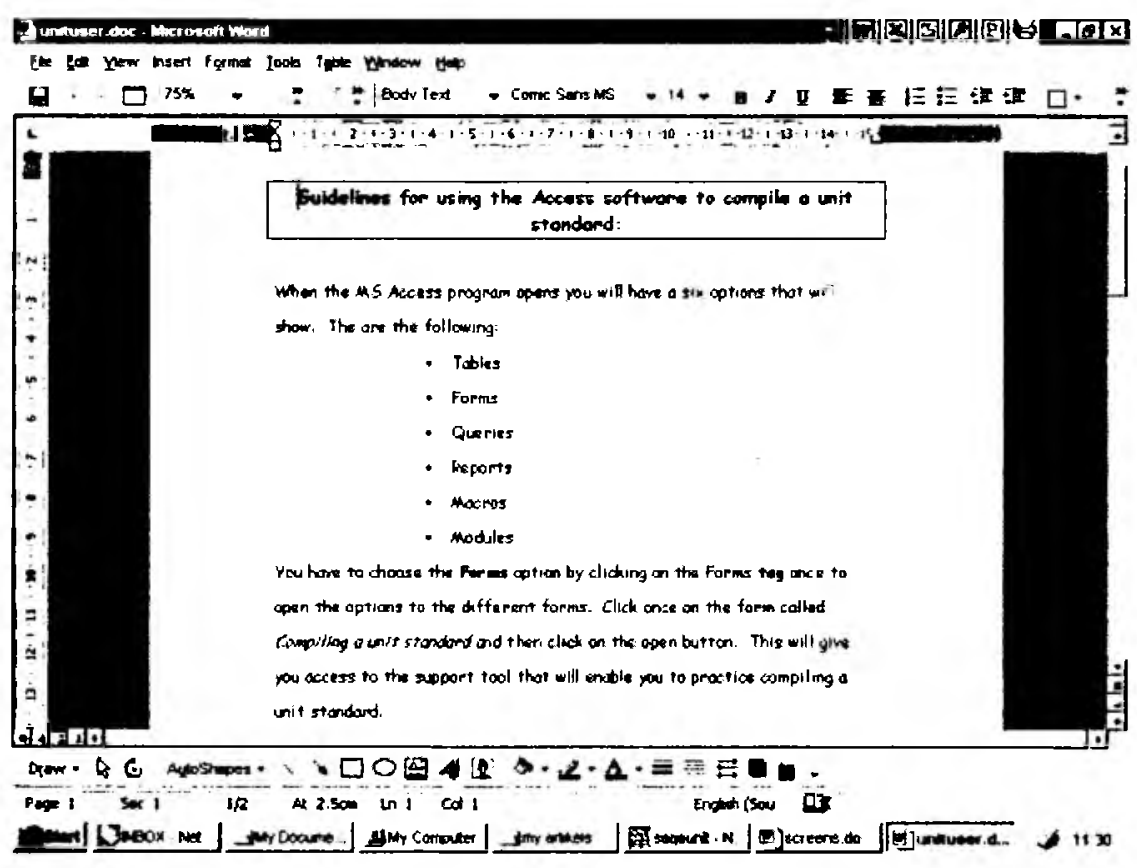

HANNAFIN, MJ \& PECK, KL 1988: The Design, Development and Implementation of Instructional Software. MacMillan Publishing Company: New York.

JONES, MG \& OKEY, JR 1995: Interface Design for Computer-based Learning Environments. http://www.hbg.psu.edu/bsed/intro/docs/ idguide/

JOSEPH, LC 1999: WWW CyberGuide Ratings for Web Site Design. http:// www.cyberbee.com/guide2.html

NEWBY, TJ; STEPIC, DA; LEHMAN, JD \& RUSSEL, JD 1996: Instructional Technology for Teaching and Learning. Merril: New Jersey.

OPPENHEIMER, $T$ 1997: The computer Delusion. The Atlantic Monthly. 280(1) 45-62. http:/ /www.theatlantic.com/issues/97jul/computer.htm

REEVES, TC 1994: Evaluation Toolkit. http://mime 1.marc.gatech.edu/MM_Tools/ evaluation.html

TROCHIM, WMK 1999: Research Methods Knowledge Base, $2^{\text {nd }}$ Edition. Cornell University.

EVALUATING INSTRUCTIONALCOMPUTER COURSEWARE. Department of Library Studies and Educational Technology. East Carolina University. http://eastnet.educ.ecu.edu/schofed/ lset/6042/software.htm http://hagar.up.ac.za/catts/ole/eel/concept-map/ cosmet2.html 